\title{
Ellipsis
}

2016

\section{Jumbled Thoughts}

Amy T. Nguyen

University of New Orleans

Follow this and additional works at: https://scholarworks.uno.edu/ellipsis

\section{Recommended Citation}

Nguyen, Amy T. (2016) "Jumbled Thoughts," Ellipsis: Vol. 43 , Article 26.

DOI: https://doi.org/10.46428/ejail.43.26

Available at: https://scholarworks.uno.edu/ellipsis/vol43/iss1/26

This Visual Art is brought to you for free and open access by the Department of English and Foreign Languages at ScholarWorks@UNO. It has been accepted for inclusion in Ellipsis by an authorized editor of ScholarWorks@UNO.

For more information, please contact scholarworks@uno.edu. 


\section{Jumbled Thoughts}

Amy Nguyen

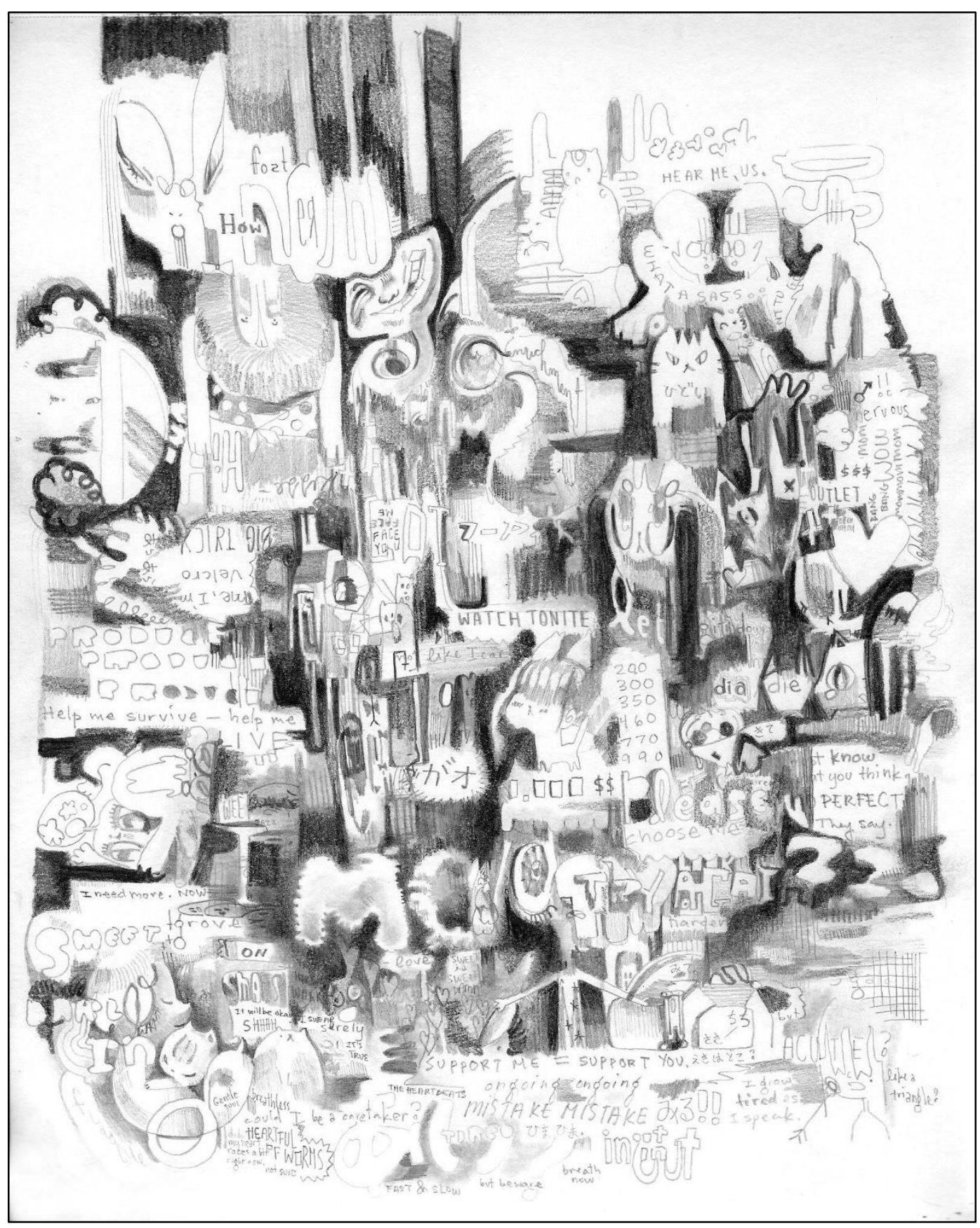

